\title{
Cadmium Exposure and Potential Health Risk from Foods in Contaminated Area, Thailand
}

\author{
Rodjana Chunhabundit \\ Graduate Program in Nutrition, Faculty of Medicine at Ramathibodi Hospital, Mahidol University, Bangkok, Thailand
}

(Received December 2, 2015; Revised December 24, 2015; Accepted January 12, 2016)

\begin{abstract}
Man-made cadmium (Cd) emissions can be transported between environmental matrices and the food chain. Food is the primary source of $\mathrm{Cd}$ exposure among general population as a consequence of the bioconcentration of $\mathrm{Cd}$ from soil. Chronic $\mathrm{Cd}$ exposure has been reported to be associated with chronic kidney disease, osteoporosis, diabetes, cardiovascular disease and cancer. The Joint FAO/WHO Expert Committee on Food Additives (JECFA) established the safe level of Cd intake as provisional tolerable monthly intake (PTMI) of $25 \mu \mathrm{g} / \mathrm{kg}$ bw in 2010. The major food groups that contribute to the most Cd exposure are rice and grains, shellfish and sea food, meat including edible offal, and vegetables. A number of studies reported the high Cd contaminated levels in foods from polluted areas in Thailand. The results are of high concern since the contaminations occur in foods that are major $\mathrm{Cd}$ contributors. Thus, in this review, the current situations of $\mathrm{Cd}$ contaminated foods in polluted areas of Thailand are summarized. In addition, the $\mathrm{Cd}$ intakes from selected scenarios are estimated to assess the potential health risk to consumers and the suggestions are also included.
\end{abstract}

Key words: Cadmium, Foods, Contaminated area, Health risk, Thailand

\section{INTRODUCTION}

Cadmium $(\mathrm{Cd})$ is used to produce a wide variety of consumer and industrial materials, such as electrode in $\mathrm{Ni}-\mathrm{Cd}$ batteries; pigments for plastics, ceramics, and glasses; stabilizers for polyvinyl chloride (PVC); coatings for steel and nonferrous metals; solar cells and electronic devices, and constituent of fungicides or fertilizers. The global mobilization of $\mathrm{Cd}$ is significantly impacted by human activities. $\mathrm{Cd}$ deposits to lands through atmospheric emissions originating from residues from coal combustion, urban refuse, mine tailings and smelter slag and waste (1). Cd is mainly a byproduct from zinc mining, smelting and refining. During the period 1997 2004, the Cd production in America did not change, in Europe it tended to decrease, whereas in Asia, it continually increased from about 43 percent to about 60 percent of worldwide $\mathrm{Cd}$ production (2). Among the world

Correspondence to: Rodjana Chunhabundit, Graduate Program in Nutrition, Faculty of Medicine at Ramathibodi Hospital, Mahidol University, Bangkok, Thailand

E-mail: rodjana.chu@mahidol.ac.th

This is an Open-Access article distributed under the terms of the Creative Commons Attribution Non-Commercial License (http:// creativecommons.org/licenses/by-nc/3.0) which permits unrestricted non-commercial use, distribution, and reproduction in any medium, provided the original work is properly cited.
Top ten, China was the first, the Republic of Korea and Japan ranked second and third of Cd refinery production in 2014 (3).

\section{CADMIUM EXPOSURE PATHWAYS}

$\mathrm{Cd}$ enters the environments through natural and various anthropogenic sources. However, the accumulation of $\mathrm{Cd}$ in the soil-plant environment mainly through anthropogenic activities such as application of phosphate fertilizers, waste water, sewage sludge and manures. The high mobility in soils make $\mathrm{Cd}$ accumulation in plants poses a serious threat to animal and human health (4). The possible pathways of human exposure to $\mathrm{Cd}$ via the food chain are shown in Fig. 1. Cd is a common contaminant found in most human foodstuffs due to the high transfer factor properties of plants. The bioconcentration of $\mathrm{Cd}$ from soil to the foodstuffs makes diet a primary source of $\mathrm{Cd}$ exposure among non-smoking, non-occupationally exposed populations. Certain foods such as shellfish, kidney, liver, mushrooms and root crops contain especially high levels of cadmium (5). Owing to the larger production sources, $\mathrm{Cd}$ exposure in Asian countries may be higher than in Europe and in USA.

In Thailand, there were a number of studies that documented the $\mathrm{Cd}$ contamination to environment including foods produced in contaminated areas. There has been some 


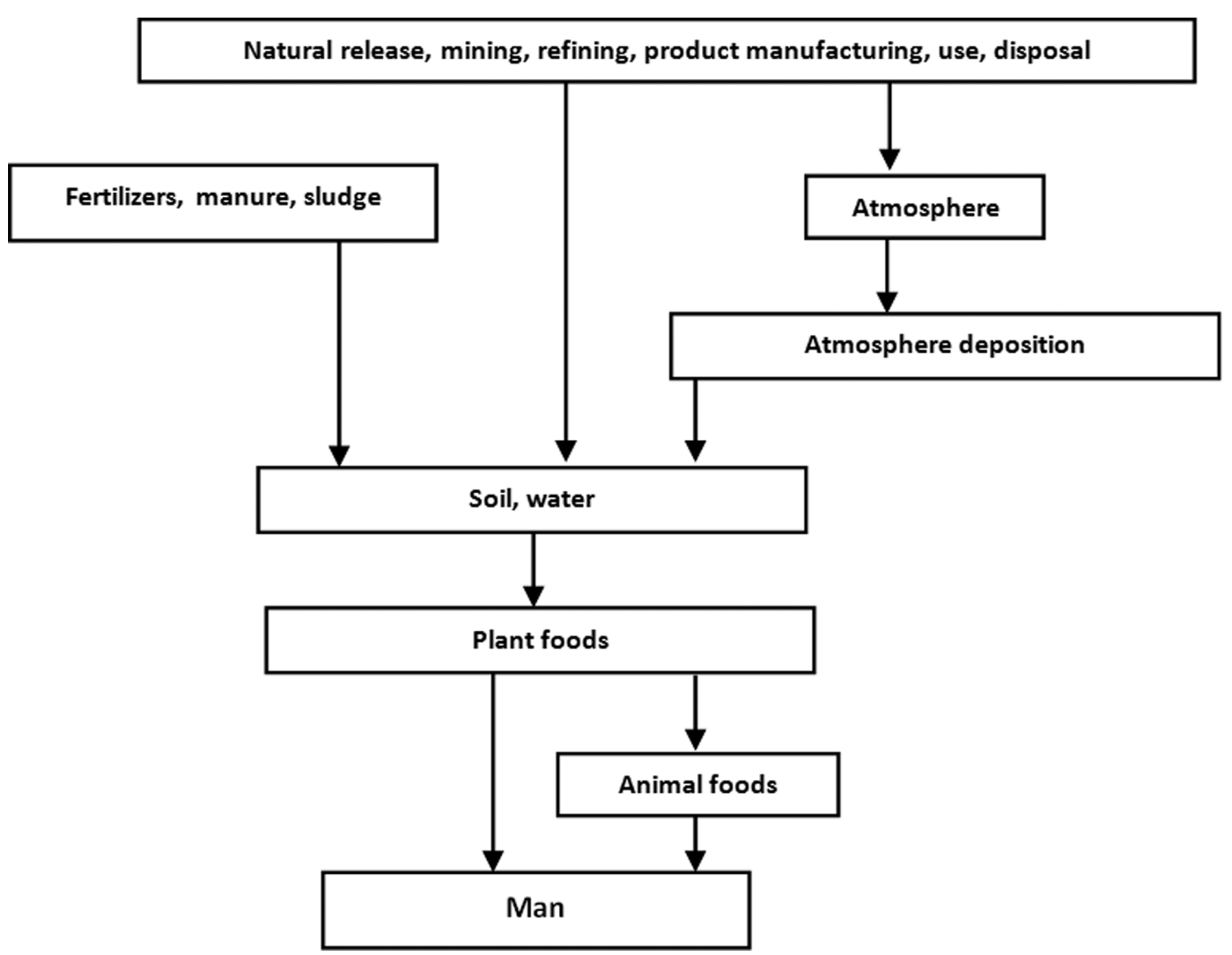

Fig. 1. Cadmium exposure from environments and foods. Man-made emissions of $\mathrm{Cd}$ from manufacture, use and disposal of cadmium containing products can be transported between environmental matrices (air, water, sludge, sediment and soil) and enter the food chain.

concern about the potential health effects resulting from the consumption of the contaminated foods by people in local polluted area and people who get the foods from distributed markets. Therefore, this review provides an update on newly identified potential mechanisms of $\mathrm{Cd}$ toxic effects that link Cd exposure with chronic diseases found in exposed population, safe intake levels and major contributors of dietary $\mathrm{Cd}$. In addition, the review also highlights the estimation of $\mathrm{Cd}$ exposure from foods in contaminated area in Thailand and their potential health risk to consumers.

\section{CADMIUM EXPOSURE AND HEALTH EFFECTS}

Kidney and Diabetic nephropathy. Chronic dietary $\mathrm{Cd}$ exposure induced renal damage is characterized by proximal tubule dysfunction. After absorbed into proximal tubule cells, the Cd-metallothionein-1 (CdMT-1) complex is stored and broken down by lysosomes. Free $\mathrm{Cd}$ accumulates in mitochondria, leads to mitochondrial dysfunction, free radical formation and apoptosis induction. Binding of $\mathrm{Cd}$ with protein sulfhydryl interferes $\mathrm{Na}^{+}-\mathrm{K}^{+}$-ATPase activity, and MAP kinases. Cd also affects the distribution of paracellular tight junction proteins and decreases transepi- thelial resistance (6). Several epidemiological studies suggest that $\mathrm{Cd}$ exposure may potentiate the effects diabetes on the kidney. A study investigated potential health effect of high $\mathrm{Cd}$ exposure in Torres Strait Islanders who consumed dugong and turtle offal as traditional seafood. There was also a high prevalence of Type 2 diabetes in these indigenous peoples. The significantly higher urinary $\mathrm{Cd}$ levels and higher proportion of urine samples with over 1 and $2 \mu \mathrm{g} \mathrm{Cd}$ per gram creatinine were observed among people with diabetes compared to those without (7). Sub-chronic Cd exposure (12 weeks) in rats showed the significant increases in blood glucose levels in Cd-treated groups. $\mathrm{Cd}$ exposure also resulted in increased glycosylated hemoglobin A (\%A1C) levels and decreased fasting serum insulin levels (8). The potential cellular mechanisms may involve $\mathrm{Cd}$ affecting glucose metabolism by direct acting on different target organs including pancreas, liver, adipose tissue and the adrenal gland. The rapid uptake of $\mathrm{Cd}$ was found in the pancreatic cells of obese-hyperglycemic animal. The high $\mathrm{Cd}$ levels significantly decreased insulin secretion from pancreatic islets cells. Subchronic Cd exposure elevated the gluconeogenesis enzymes activity in liver cells. In isolated rat adipocytes, $\mathrm{Cd}$ decreased expression of glucose transporter 
(GLUT4) and reduced glucose transport activity. Cd also enhanced the release of catecholamines from adrenal gland result in increased blood glucose levels. In addition, $\mathrm{Cd}$ exhibited direct effects on glucose metabolism in the kidney cells by decreasing the glucose uptake and expression of SGLT1 glucose symporter. Moreover, the activities of gluconeogenesis enzymes were increased in kidney cells of rat exposed to $\mathrm{Cd}(9)$.

Bone. The population-based study in Flemish women living in districts with low to moderate environmental $\mathrm{Cd}$ pollution showed the association between osteoporosis and environmental $\mathrm{Cd}$ exposure. The explanation of this finding was that $\mathrm{Cd}$ decreased bone density indirectly through hypercalciuria resulting from renal tubular dysfunction. However, the study of Schutte et al. performed in 294 women who were the former Flemish participants showed that $\mathrm{Cd}$ also decreased bone density through a direct osteotoxic effect. The evidence was shown by a consistent association between the urinary crosslinks biomarkers of bone resorption and biomarkers of lifetime and recent exposure to $\mathrm{Cd}$. In addition, the decreased serum parathyroid hormone (PTH) levels with higher $\mathrm{Cd}$ exposure might indicate the induction of calcium release from bone tissue (10). More recent study found that urinary $\mathrm{Cd}$ (UCd) predicted bone mineral density, with increased UCd concentrations associated with decreased bone density. UCd concentrations were positively correlated with bone resorption, these results suggested for low $\mathrm{Cd}$ exposure being of concern for the health of older women (11). There were the evidences suggested that even without Cd-induced renal tubular dysfunction, low-level environmental exposure to $\mathrm{Cd}$ seemed to mobilize bone minerals from the skeletal tissue. Adverse effects on bone apparently occurred at lower exposures than kidney effects (UCd $0.5 \sim 2 \mathrm{vs}>4 \mu \mathrm{g} / \mathrm{g}$ creatinine, respectively) (12).

Cardiovascular disease. $\mathrm{Cd}$ initiates atherosclerosis and promotes progression as shown by induction of endothelial dysfunction in vitro and acceleration of atherosclerotic plaque formation in vivo. Induction of increased membrane permeability, DNA strand breaks, growth inhibition and necrosis were presented in cultured human umbilical vein endothelial cells (HUVECs) exposed to $\mathrm{Cd}$. $\mathrm{Cd}$ in drinking water caused endothelial damage and shifted the lipid profiles of ApoE -knockout mice toward more atherogenic pattern. The plaque surface area in Cd-treated mice was significantly increased compared to the controls (13). The mechanisms of $\mathrm{Cd}$ promote atherosclerosis may involve increasing reactive oxygen species formation, interfering anti-oxidative responses. $\mathrm{Cd}$ indirectly enhanced free radical generation by replacing iron and copper in cytoplasmic and membrane proteins, the unbound free or poorly chelated copper and iron ions that participated in oxidative stress via Fenton reactions subsequently increased (14). The increased blood pressure also related to kidney damage from Cd exposure. The Korean National Health and Nutrition Examination Survey (KNHANES) reported that the association between $\mathrm{Cd}$ exposure and chronic kidney disease was found in the adults with hypertension or diabetes (15). A systematic review of twelve epidemiologic studies conducted by Tellez-Plaza et al. illustrated the association between $\mathrm{Cd}$ exposure and cardiovascular disease, especially for coronary heart disease. The pooled relative risks ( $95 \%$ confidence interval) for cardiovascular disease, coronary heart disease, stroke, and peripheral arterial disease were: 1.36 (95\%CI: 1.11, 1.66), 1.30 (95\% CI: 1.12, 1.52), 1.18 (95\%CI: $0.86,1.59)$, and 1.49 (95\%CI: $1.15,1.92)$, respectively (16).

Cancer. Because of the sufficient evidences in humans for the carcinogenicity of $\mathrm{Cd}$ and its compounds, International Agency for Research on Cancer re-evaluated and classified $\mathrm{Cd}$ and its compounds as carcinogens to humans (Group 1). $\mathrm{Cd}$ and $\mathrm{Cd}$ compounds cause cancer of the lung and are positively associated with kidney and prostate cancer (17). Cd induces cancer by multiple mechanisms. Oxidative stress plays a central role in $\mathrm{Cd}$ carcinogenesis by involvement in Cd-induced aberrant gene expression, inhibition of DNA damage repair, and apoptosis (18). Cd is not redox active metal and cannot directly initiate Fenton reaction. The mechanism by which $\mathrm{Cd}$ initiates ROS formations may be through creating cellular thiol redox imbalance that leads to decreased intracellular glutathione content and reducing activities of cellular antioxidant enzymes. These events result in ROS accumulation and intracellular oxidative stress. ROS can induce DNA damage and can also interfere with cell signaling. Furthermore, $\mathrm{Cd}$ at concentration relevant to human exposure interacts with DNA repair mechanisms, cell cycle checkpoints and apoptosis. All proposed mechanisms involved in $\mathrm{Cd}$ induced genomic instability (19). Cd also plays a role in epigenetic alteration. $\mathrm{Cd}$ exposure results in DNA hypermethylation and hypomethylation. Acute $\mathrm{Cd}$ exposure decreases DNA methylation via noncompetitive inhibition of DNA methyltransferase (DNMT) activity, whereas chronic $\mathrm{Cd}$ exposure results in global DNA hypermethylation and enhanced DNMT activity. Long-term Cd treatment resulted in increased DNMT3b transcript levels leading to increased DNMT activity, promoter hypermethylation and loss of expression of tumor suppressor genes RASSF1A and p16. Cd has been shown to alter histone modification and microRNA levels in vitro (20).

\section{SAFE LEVEL OF CADMIUM INTAKE}

The Joint FAO/WHO Expert Committee on Food Additives (JECFA) established the safe level of $\mathrm{Cd}$ intake as pro- 
Table 1. Major food contributors to dietary Cd intake

\begin{tabular}{|c|c|c|c|c|}
\hline & \multicolumn{3}{|c|}{ The top three major contributors } & \multirow{2}{*}{ References } \\
\hline & 1 & 2 & 3 & \\
\hline USA & $\begin{array}{l}\text { Shellfish and food containing } \\
\text { sea foods }(15.36 \%)\end{array}$ & $\begin{array}{l}\text { Wheat dishes and bread } \\
(11.39 \%)\end{array}$ & Potatoes $(5.31 \%)$ & $(23)$ \\
\hline New Zealand & $\begin{array}{l}\text { Foods excluding potatoes, } \\
\text { oysters, mussels, bread, carrots }\end{array}$ & Potatoes & Oysters & $(24)$ \\
\hline Korea & Rice (31\%) & Fruits $(28 \%)$ & $\begin{array}{l}\text { Vegetables excluding potatoes } \\
\text { and legumes }(18 \%)\end{array}$ & $(25)$ \\
\hline Europe & $\begin{array}{l}\text { Grains and grain products } \\
(26.9 \%)\end{array}$ & $\begin{array}{l}\text { Vegetables and vegetable prod- } \\
\text { ucts }(16.0 \%)\end{array}$ & Meat and edible offal $(7.7 \%)$ & $(26)$ \\
\hline Sweden & Bread (33\%) & Potatoes $(18 \%)$ & Cereals excluding bread (15\%) & $(27)$ \\
\hline Hong Kong & Vegetable and products $(31 \%)$ & $\begin{array}{l}\text { Fish, seafood and products } \\
(26 \%)\end{array}$ & $\begin{array}{l}\text { Cereals and their products } \\
(21 \%)\end{array}$ & $(28)$ \\
\hline Vietnam & Rice $(90 \%)$ & - & - & $(29)$ \\
\hline India (Vadodara) & Cereals $(31 \%)$ & Curd (20\%) & Fruits $(17 \%)$ & $(30)$ \\
\hline China & Meat $(33-40.9 \%)$ & Rice $(26.8-40.8 \%)$ & Vegetables (12.4-16.2\%) & $(31)$ \\
\hline Norway & Grains and grain products & $\begin{array}{l}\text { Vegetable and vegetable prod- } \\
\text { ucts }\end{array}$ & Starchy roots and tubers & $(32)$ \\
\hline
\end{tabular}

visional tolerable weekly intake (PTWI) of $7 \mu \mathrm{g} / \mathrm{kg}$ bw in 1988. The last evaluation was performed in 2010. A large meta-analysis of studies measuring the dose-response relationship between $\beta 2$-microglobulin $(\beta 2 \mathrm{MG})$ and $\mathrm{Cd}$ excretion in urine showed that the urinary excretion of less than $5.24 \mu \mathrm{g} \mathrm{Cd} / \mathrm{g}$ creatinine was not associated with an increased excretion of $\beta 2 \mathrm{MG}$. A steep increase in $\beta 2 \mathrm{MG}$ excretion appeared to correlate with the higher urinary cadmium levels. The dietary $\mathrm{Cd}$ exposure that equates to the breakpoint was estimated to be $0.8 \mu \mathrm{g} / \mathrm{kg}$ bw per day or about $25 \mu \mathrm{g} / \mathrm{kg}$ bw per month. Due to the long half-life of $\mathrm{Cd}$ in human kidneys, the committee considered that a monthly value was more appropriate. The PTWI of $7 \mu \mathrm{g} / \mathrm{kg}$ bw was therefore withdrawn and the new provisional tolerable monthly intake (PTMI) of $25 \mu \mathrm{g} / \mathrm{kg}$ bw was established (21).

In 2009, the Panel on Contaminants in the Food Chain of European Food Safety Authority (EFSA) issued an opinion in which the PTWI should be reduced to a tolerable weekly intake (TWI) of $2.5 \mu \mathrm{g} / \mathrm{kg}$ bw. This intake level showed $95 \%$ of the population would have $\mathrm{UCd}<1 \mu \mathrm{g} \mathrm{Cd} / \mathrm{g}$ creatinine (benchmark dose lower limit; BMDL5 of elevated $\beta 2 \mathrm{MG})$ by age 50 years. This opinion was subsequently confirmed in 2011 (22).

Maintaining the $\mathrm{Cd}$ intakes below the PTMI or TWI is needed to be done to prevent health risk from Cd contamination. The major dietary sources of $\mathrm{Cd}$ exposure were therefore identified in many countries. The current data of specific foods contributing to dietary exposure to $\mathrm{Cd}$ is shown in Table 1. The food groups that contribute to the most $\mathrm{Cd}$ exposure among different countries over more than a decade are rice and grains, shellfish and sea food, meat including edible offal, and vegetables.

\section{CADMIUM EXPOSURE FROM CONTAMINATED FOODSTUFFS}

Anthropogenic activities and industrial uses enhance $\mathrm{Cd}$ accumulation in plant- and animal-based foods. A number of studies reported the high Cd contaminated levels in foods from polluted areas in Thailand. The results are of high concern since the contaminations occur in foods that are major Cd contributors.

Rice. There was soil and associated rice grain $\mathrm{Cd}$ contamination downstream of an actively mined zone of $\mathrm{Zn}$ mineralization in western region of Thailand. Over $90 \%$ of rice grain samples collected during 2001 and 2002 contained $\mathrm{Cd}$ concentrations exceeding the Codex Committee on Food Additives and Contaminants draft Maximum Permissible Level for rice grain of $0.2 \mathrm{mg} \mathrm{kg}^{-1}$. The rice-based agricultural system was located within Phatat Pha Daeng sub-district, Mae Sot, Tak Province. The paddy fields received irrigation from the Mae Tao and Mae $\mathrm{Ku}$ creeks that were found to contain markedly elevated Cd levels. Both creeks passed through a zinc rich area where the zinc mine had been actively operated for more than 20 years. The estimated weekly intake (WI) values for $\mathrm{Cd}$ via rice consumption ranged from 20 to $82 \mathrm{mg} \mathrm{Cd}$ per $\mathrm{kg}$ bw (33). Most $(88.0 \%)$ of the people living in district mainly consumed rice grown locally in the contaminated areas. About $11.1 \%$ of the people purchased rice from Mae Sot markets that consisted of rice harvested from both contaminated and 
uncontaminated areas. The highest proportion of persons who had urinary $\mathrm{Cd}>5 \mu \mathrm{g} / \mathrm{g}$ creatinine was observed among those who consumed locally grown rice. These findings may imply that dietary $\mathrm{Cd}$ was the major source of excessive exposure in population (34).

Zwicker et al. compared the Cd contents in eight different varieties of commercial rice purchased from markets in Bangkok with eleven rice samples from known contaminated areas. All the commercial rice samples had Cd concentrations well below the limit proposed by the Codex Committee on Food Additives and Contaminants of $0.4 \mathrm{mg}$ $\mathrm{kg}^{-1}$ for polished rice. The Cd concentrations in most contaminated rice samples were very close to the limit, and only one exceeded the limit. However, because of high consumption as a staple food, 6 in 11 values of the $\mathrm{Cd}$ intake from contaminated rice exceed the proposed PTMI 0.025 $\mathrm{mg} / \mathrm{kg} \mathrm{BW}(35)$.

Recently, Sriprachote et al. evaluated the current situation of the Cd-polluted paddy fields in the Pha Te village, one of the villages located in the Mae Tao creek watershed. The Cd concentration in home-consumed rice grains collected from all households in the village ranged from 0.04 to $1.75 \mathrm{mg} \mathrm{Cd} \mathrm{kg}$. Moreover, more than half of the rice from households contained $\mathrm{Cd}$ levels higher than the CODEX standard level of $0.4 \mathrm{mg} \mathrm{Cd} \mathrm{kg}^{-1}$ polished rice. Mapping distribution of the paddy fields of the Pha Te villagers together with the rice $\mathrm{Cd}$ levels showed that rice grains containing $\mathrm{Cd}$ more than $0.8 \mathrm{mg} \mathrm{Cd} \mathrm{kg} \mathrm{mere}^{-1}$ wroduced in the paddy fields located along the main stream of the creek (36).

Offal. There is high concern about the exposure to $\mathrm{Cd}$ in the foods from animal sources, especially offal which is a major source of $\mathrm{Cd}$ to some sections of the population. Pig liver and kidney are habitually eaten by Thais. Yarmak et al. reported the $\mathrm{Cd}$ levels in pig kidney samples from Maesot district ranged $0.09 \sim 40.14 \mathrm{mg} \mathrm{kg}^{-1}$, compared to those from Bangkok ranged 0.01 20.21 mg kg-1 (37). Nookabkaew et al. studied the contents of trace elements including some toxic elements in various foodstuffs normally eaten by infant and young school children. The samples collected from local markets, big supermarkets and grocery stores in Bangkok illustrated $\mathrm{Cd}$ in the range of $0.28 \sim 3.68 \mathrm{mg} \mathrm{kg}^{-1}$ for pig livers and range of $0.38 \sim 10.82 \mathrm{mg} \mathrm{kg}^{-1}$ for pig kidneys (38). More recently, $\mathrm{Cd}$ in animal based foods from the local markets in northeastern region Thailand was determined. It was found that average Cd levels in liver and kidney of pig were 0.36 and $0.75 \mathrm{mg} \mathrm{kg}^{-1}$ that were with in Thailand regulatory limits for $\mathrm{Cd}$ in pig liver and kidney $\left(0.5,1 \mathrm{mg} \mathrm{kg}^{-1}\right)$ (39).

Vegetables. The leafy vegetables such as spinach and lettuce may have considerably higher Cd levels. A recent report in 2013, for vegetables collected from local markets, big supermarkets and grocery stores in Bangkok, potato had the highest $\mathrm{Cd}$ concentration. The toxic elements including $\mathrm{Cd}$ were higher in leafy vegetables than in root vegetables. However, $\mathrm{Cd}$ concentrations in all vegetables were still lower than the maximum levels of $\mathrm{Cd}$ as regulated by Codex Committee on Food Additives and Contaminants (CODEX Standard 193-1995) at $0.2 \mathrm{mg} \mathrm{kg}^{-1}$ (38).

The province of Southern Thailand, Surat Thani has served as a mining industry for many decades. The health problems from heavy metal pollution due to old mining sites in the neighboring provinces had been indicated. The local vegetables available in four districts in Surat Thani province including Pak-Leang (Gnetum gnemon Linn.), Pak-Waen (Marsilea crenata Presl.), Mun-Poo (Glochidion littorale Blume Baill.) and Chamuang (Garcinia cowa Roxb.) were evaluated for $\mathrm{Cd}$ contents due to their common intake. Pak-Waen, Mun-Poo, and Chamuang contained $\mathrm{Cd}$ ranging from 0.18 to $0.86,0.08$ to 1.66 and 0.17 to $0.78 \mathrm{mg} \mathrm{kg}^{-1}$, respectively. The wide range of average $\mathrm{Cd}$ concentration reflected a greater variation in $\mathrm{Cd}$ concentration in each vegetable collected from different sampling site. Only Pak-Leang had $\mathrm{Cd}$ concentrations below the maximum allowable level for leafy vegetables of Thai standard (TAS 9007-2005) $0.2 \mathrm{mg} \mathrm{kg}^{-1}$ (40).

Shellfish. Two studies determined the concentration of $\mathrm{Cd}$ in seafoods derived from local market and local shops in Rayong that is a major agricultural and industrial province of Thailand. Kerdthep et al. reported the $\mathrm{Cd}$ concentration in 13 most consumed seafood species were $0.009 \sim 0.731 \mathrm{mg}$ $\mathrm{kg}^{-1}$. The seafood having the highest $\mathrm{Cd}$ concentration was blood cockle (41). In 2015, Rangkadilok et al. also determined the $\mathrm{Cd}$ concentrations in the edible flesh of farmed shellfish around the Map Ta Phut Industrial Estate area. The greatest concentration range of $\mathrm{Cd}\left(0.74\right.$ to $\left.1.95 \mathrm{mg} \mathrm{kg}^{-1}\right)$ was found in S. inaequivalvis flesh (42). From these two studies, the highest $\mathrm{Cd}$ contaminations were found in shellfish blood cockles. Such contaminated levels did not exceed the Australia New Zealand Food standard maximum level of $\mathrm{Cd}$ in mollusks $\left(2.0 \mathrm{mg} \mathrm{kg}^{-1}\right)$.

To assess the potential health risk to consumer, the $\mathrm{Cd}$ intake from selected scenarios was estimated by using database of food consumption of Thai people <Version1.0.6 $>$ (43). The estimated Cd intakes are then compared with current provisional tolerable monthly intake (PTMI) for $\mathrm{Cd}$ $(0.025 \mathrm{mg} / \mathrm{kg} \mathrm{BW})$ as shown in Table 2 .

Estimated total monthly intakes of $\mathrm{Cd}$ from selected local contaminated foods are shown in Table 2. The present results illustrate the impact of $\mathrm{Cd}$ contamination level on exposure expressed as \% PTMI. The first highest contributor to the extremely exceeding PTMI is pig kidney. Even small amount of average consumption by consumers only, pig kidneys from Mae Sot polluted area contribute $\mathrm{Cd}$ exposure $>12$ times of PTMI, whereas those from Bang- 
Table 2. Estimation of $\mathrm{Cd}$ intake from different contaminated food sources

\begin{tabular}{|c|c|c|c|c|}
\hline Foods & Consumption $^{\mathrm{a}}$ (g/day) & Cd concentration $(\mathrm{mg} / \mathrm{g})$ & Estimated monthly intake $(\mathrm{mg} / \mathrm{kg} \mathrm{bw})^{\mathrm{d}}$ & \%PTMI \\
\hline \multirow{2}{*}{ Rice } & \multirow{2}{*}{$130^{\mathrm{b}}$} & $0.578 \times 10^{-3}(35)$ & 0.042 & 168 \\
\hline & & $1.75 \times 10^{-3}(36)$ & 0.126 & 504 \\
\hline \multirow{3}{*}{ Pig kidney } & \multirow{3}{*}{$14^{\mathrm{c}}$} & $20.21 \times 10^{-3}(37)$ & 0.157 & 628 \\
\hline & & $40.14 \times 10^{-3}(37)$ & 0.312 & 1,248 \\
\hline & & $10.82 \times 10^{-3}(38)$ & 0.084 & 336 \\
\hline Pig liver & 17 & $3.68 \times 10^{-3}(38)$ & 0.035 & 140 \\
\hline Chamuang & \multirow{2}{*}{14} & $0.78 \times 10^{-3}(40)$ & 0.006 & 24 \\
\hline Mun-Poo vegetable & & $1.66 \times 10^{-3}(40)$ & 0.013 & 52 \\
\hline Blood cockle & 39 & $1.95 \times 10^{-3}(42)$ & 0.042 & 168 \\
\hline
\end{tabular}

Notes: Food consumptions were adapted from food consumption of Thai people (2007 2010), National Bureau of Agricultural Community and Food Standards.

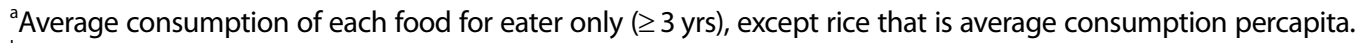

${ }^{b}$ Consumption of rice grain converted from cooked rice.

'Consumption of pig kidney estimated from $1 / 3$ total consumption of pig offal, excluding pig liver.

${ }^{\mathrm{d} C}$ Calculation based on the average body weight of consumers aged $\geq 3$ years $=54 \mathrm{~kg}$.

kok city give ingested $\mathrm{Cd}>3$ to 6 folds PTMI. The second contributor to extreme $\mathrm{Cd}$ exposure is rice. The commercial rice from contaminated area which had $\mathrm{Cd}$ slightly exceed Thai maximum limit causes intake of $\mathrm{Cd}$ exceed the PTMI by about 1.5 fold. The highest $\mathrm{Cd}$ level in rice collected more recently from households in Mae Sot district results the exposure 5 times PTMI.

Blood cockles, a popular type of edible shellfish especially South East Asian cuisines represent as another major food of animal origin contribute to dietary $\mathrm{Cd}$. Even the $\mathrm{Cd}$ content within the standard maximum limit, average consumption of consumers only can make the exposure greater than PTMI.

The average consumption of Chamuang and Mun-Poo vegetables grown in area contaminated $\mathrm{Cd}$ from natural and anthropogenic sources leads to the exposure range of $25 \%$ $50 \%$ PTMI. Chamuang is well known local vegetable used in a pork curry that is a traditional food from East of Thailand. Mun-poo is commonly more consumed as side dish vegetable by local population. It is possible that the consumption as well as $\mathrm{Cd}$ exposure might be largely increased because some Thai people like to eat a plenty of fresh vegetables with chili or curry paste.

\section{HEALTH IMPACTS ON POPULATION EXPOSED TO CADMIUM}

In 2001 2004, crops including rice grown in area near a zinc mine in Mae Sot District, Tak Province, were found to contain markedly elevated $\mathrm{Cd}$ levels. People exposed to $\mathrm{Cd}$ by consuming these food crops were examined for urinary Cd. About $95.1 \%$ of persons with high urinary $\mathrm{Cd}$ levels ( $>5 \mu \mathrm{g} / \mathrm{g}$ creatinine) were then screened for renal dysfunction in late 2004. The findings revealed that a significant proportion of these persons had abnormal renal measure- ments, including $\beta 2$-microglobulinuria, proteinuria, high fractional excretion of phosphate, hypokalemia, and low glomerular filtration rate (GFR) $(44,45)$.

The reduction of excessive dietary $\mathrm{Cd}$ intake was performed during 2004 2007 by government purchased all rice grown in the contaminated areas, paid compensation for no food cultivation and supported the production of nonfood crops. After reduction of $\mathrm{Cd}$ exposure strategies had been done, persons with high urinary $\mathrm{Cd}$ levels were 5 years followed up for chronic Cd toxicity in 2010. The results of significant increases in urinary $\beta 2-\mathrm{MG}$, urinary total protein and serum creatinine, and a decrease in GFR were found in persons both with and without reduction in $\mathrm{Cd}$ intake. Significant increases in prevalence of hypertension, diabetes and urinary stones were also detected. These findings indicate the progress of renal toxic effects in persons prolonged exposed to excessive $\mathrm{Cd}$, even after exposure was reduced (46).

\section{CONCLUSION}

The level of $\mathrm{Cd}$ in foods from polluted area is very high. Only one contamination source may pose a significant public health risk to the local communities. The high consumption as staple food makes rice is the most important source of dietary $\mathrm{Cd}$ exposure. Increase risk of $\mathrm{Cd}$ exposure also results from other specific foods include animal kidney, blood cockle and local vegetables. $\mathrm{Cd}$ can be accessible to the food chain for a long time. Over a past decade, despite being lower, $\mathrm{Cd}$ contents in contaminated rice samples from Mae Sot still in a range mediating health effects to the consumers. Biomarkers monitoring showed that dietary $\mathrm{Cd}$ exposure was likely related to the adverse health outcomes. However, the progress of health effects did not correlate with the reduction of $\mathrm{Cd}$ in environment or foods. There- 
fore the protection from $\mathrm{Cd}$ exposure is more important for health implementation.

Animal kidney is the first organ to reach the limit of safe for human consumption. It is noteworthy that the highly exceeded maximum limit levels of $\mathrm{Cd}$ were identified in animal kidneys from both inside and outside the local contaminated area. Many Thai habitually like to consume edible offal and commonly used them in several Thai dishes. To solve the problem, the regular monitoring program should be implemented and the high-risk products should be removed from the food chain. In addition, consumer warning and education on specific food contaminant should be required since effective treatment or regimens for removing $\mathrm{Cd}$ accumulation in the body have not yet been available. Self-protection by avoiding cadmium intake would be the most effective measure. The Thai maximum limit for $\mathrm{Cd}$ in shellfish still has not been established. Average consumption of blood cockle contaminated with $\mathrm{Cd}$ in level close to the maximum limit set by Australia New Zealand Food Standards lead to the exposure exceeded PTMI. Because blood cockle is widely consumed by Thai, the $\mathrm{Cd}$ concentration in this species distributed to market in every region of Thailand should be determined. The more accurate risk assessment and maximum limit consideration are needed to ensure the protection of Thai consumers. Apart from being a good source of nutrients, Thai local vegetables are known for their therapeutic value. More information on $\mathrm{Cd}$ contents of the various types of local vegetables in contaminated area and quantity of consumption should be determined to assess the potential health risks to population who consume more local vegetables.

\section{REFERENCES}

1. Faroon, O., Ashizawa, A., Wright, S., Tucker, P., Jenkins, K., Ingerman, L. and Rudisill, C. (2012) Toxicological profile of cadmium, agency for toxic substances and disease registry. Atlanta, 273-274.

2. United Nations Environment Programme. (2010) Final review of scientific information on cadmium. Chemicals Branch DTIE, UN, pp. 87-89.

3. U.S. Geological Survey. (2015) Mineral commodity summaries 2015, U.S. Geological Survey, Reston, pp. 36-37.

4. Sarwar, N., Saifullah, Malhi, S.S., Zia, M.H., Naeem, A., Bibia, S. and Farida, G. (2010) Role of mineral nutrition in minimizing cadmium accumulation by plants. J. Sci. Food Agric., 90, 925-937.

5. Satarug, S., Garrett, S.H., Sens, M.A. and Sens, D.A. (2010) Cadmium, environmental exposure, and health outcomes. Environ. Health Perspect., 118, 182-190.

6. Sabath, E. and Robles-Osorio, M.L. (2012) Renal health and the environment: heavy metal nephrotoxicity. Nefrologia, 32, 279-286.

7. Haswell-Elkins, M., Imray, P., Satarug, S., Moore, M.R. and O'dea, K. (2007) Urinary excretion of cadmium among Torres Strait Islanders (Australia) at risk of elevated dietary expo- sure through traditional foods. J. Exposure Anal. Environ. Epidemiol., 17, 372-377.

8. Edwards, J.R., Diamantakos, E.A., Peuler, J.D., Lamar, P.C. and Prozialeck, W.C. (2007) A novel method for the evaluation of proximal tubule epithelial cellular necrosis in the intact rat kidney using ethidium homodimer. BMC Physiol., 7, 1-14.

9. Edwards, J.R. and Prozialeck, W.C. (2009) Cadmium, diabetes and chronic kidney disease. Toxicol. Appl. Pharmacol., 238, 289-293.

10. Schutte, R., Nawrot, T.S., Richart, T., Thijs, L., Vanderschueren, D., Kuznetsova, T., van Hecke, E., Roels, H.A. and Staessen, J.A. (2008) Bone resorption and environmental exposure to cadmium in women: a population study. Environ. Health Perspect., 116, 777-783.

11. Callana, A.C., Devineb, A., Qi, L., Ng, J.C. and Hinwood, A.L. (2015) Investigation of the relationship between low environmental exposure to metals and bone mineral density, bone resorption and renal function. Int. J. Hyg. Environ. Health, 218, 444-451.

12. Åkesson, A., Barregard, L., Bergdahl, I.A., Nordberg, G.F., Nordberg, M. and Skerfving, S. (2014) Non-renal effects and the risk assessment of environmental cadmium exposure. Environ. Health Perspect., 122,431-438.

13. Messner, B., Knoflach, M., Seubert, A., Ritsch, A., Pfaller, K., Henderson, B., Shen, Y.H., Zeller, I., Willeit, J., Laufer, G., Wick, G., Kiechl, S. and Bernhard, D. (2009) Cadmium is a novel and independent risk factor for early atherosclerosis mechanisms and in vivo relevance. Arterioscler. Thromb. Vasc. Biol., 29, 1392-1398.

14. Jomova, K. and Valko, M. (2011) Advances in metal-induced oxidative stress and human disease. Toxicology, 283, 65-87.

15. Kim, N.H., Hyun, Y.Y., Lee, K.B., Chang, Y., Rhu, S., Oh, K.H. and Ahn, C. (2015) Environmental heavy metal exposure and chronic kidney disease in the general population. $J$. Korean Med. Sci., 30, 272-277.

16. Tellez-Plaza, M., Jones, M.R., Dominguez-Lucas, A., Guallar, E. and Navas-Acien, A. (2013) Cadmium exposure and clinical cardiovascular disease: a systematic review. Curr. Atheroscler. Rep., 15, 356.

17. International Agency for Research on Cancer. (2012) IARC Monographs, Lyon, 100C, 141.

18. Joseph, P. (2009) Mechanisms of cadmium carcinogenesis. Toxicol. Appl. Pharmacol., 238, 272-279.

19. Filipic, M. (2012) Mechanisms of cadmium induced genomic instability. Mutat. Res., 733, 69-77.

20. Ryu, H.W., Lee, D.H., Won, H.R., Kim, K.H., Seong, Y.J. and Kwon, S.H. (2015) Influence of toxicologically relevant metals on human epigenetic regulation. Toxicol. Res., 31, 1-9.

21. World Health Organization (2011) Safety evaluation of certain food additives and contaminants/prepared by the seventythird meeting of the Joint FAO/WHO Expert Committee on Food Additives (JECFA), Geneva, pp. 305-380.

22. EFSA Panel on Contaminants in the Food Chain (2011) Scientific Opinion: Statement on tolerable weekly intake for cadmium. EFSA J., Available from: www.efsa.europa.eu/efsajournal.

23. Moschandreas, D.J., Karuchit, S., Berry, M.R., O'rourke M.K., LO, D., Lebowitz M.D. and Robertson, G. (2002) Exposure apportionment: Ranking food items by their contri- 
bution to dietary exposure. J. Exposure Anal. Environ. Epidemiol., 12, 233-243.

24. New Zealand Food Safety Authority (NZFSA). (2009) New Zealand total diet study (NZTDS), NZFSA, Wellington, pp. 60 .

25. Kima, M. and Wolt, J.D. (2011) Probabilistic risk assessment of dietary cadmium in the South Korean population. Food Addit. Contam. Part A Chem. Anal. Control Exposure Risk Assess., 28, 62-70.

26. European Food Safety Authority. (2012) Scientific Report of EFSA: Cadmium dietary exposure in the European population. EFSA J., Available from: www. efsa. europa.eu/efsajournal.

27. Julin, B., Wolk, A., Johansson, J.E., Andersson, S.O., Andrén, O. and Akesson, A. (2012) Dietary cadmium exposure and prostate cancer incidence: a population-based prospective cohort study. Br. J. Cancer, 107, 895-900.

28. Centre for Food Safety (2013) The first Hong Kong total diet study: metallic contaminants. Queensway, pp. 29.

29. Marcussen, H., Jensen, B.H., Petersen A. and Holm, P.E. (2013) Dietary exposure to essential and potentially toxic elements for the population of Hanoi, Vietnam. Asia Pac. J. Clin. Nutr., 22, 300-311.

30. Chandorkar, S. and Deota, P. (2013) Heavy metal content of foods and health risk assessment in the study population of vadodara. Curr. World Environ., 8, 291-297.

31. Yuan, X., Wang, J., Shangc, Y. and Suna, B. (2014) Health risk assessment of cadmium via dietary intake by adults in China. J. Sci. Food Agric., 94, 373-380.

32. Norwegian Scientific Committee for Food Safety (VKM). (2015) Risk assessment of dietary cadmium exposure in the Norwegian population. Opinion of the Panel on Contaminants of the Norwegian Scientific Committee for Food Safety, VKM Report 2015:12, Oslo, pp. 49.

33. Simmons, R.W., Pongsakul, P., Saiyasitpanich, D. and Klinphoklap, S. (2005) Elevated levels of cadmium and zinc in paddy soils and elevated levels of cadmium in rice grain downstream of a zinc mineralized area in Thailand: Implications for public health. Environ. Geochem. Health, 27, 501511.

34. Swaddiwudhipong, W., Limpatanachote, P., Mahasakpan, P., Krintratun, S. and Padungtod, C. (2007) Cadmium-exposed population in Mae Sot district, Tak province: 1. Prevalence of high urinary cadmium levels in the adults. J. Med. Assoc. Thailand, 90, 143-148.

35. Zwicker, R., Promsawad, A., Zwicker, B.M. and Laoharojanaphand, S. (2010) Cadmium content of commercial and contaminated rice, oryza sativa, in Thailand and potential health implications. Bull. Environ. Contam. Toxicol., 84, 285288.

36. Sriprachote, A., Kanyawongha, P., Ochiai, K. and Matoh, T. (2015) Current situation of cadmium-polluted paddy soil, rice and soybean in the Mae Sot District, Tak Province, Thailand. Soil Sci. Plant Nutr., 58, 349-359.

37. Yatmark, P., Nakthong, C. and Trakranrungsie, N. (2010) Comparative evaluation of cadmium contents in livestock's kidney from Measot district, Tak province and the SW vicinity of Bangkok. Thailand J. Toxicol., 25, 81-89.

38. Nookabkaewa, S., Rangkadilokab, N., Akibb, C.A., Tuntiwigitc, N., Saehuna, J. and Satayavivadabd, J. (2013) Evaluation of trace elements in selected foods and dietary intake by young children in Thailand. Food Addit Contam: Part B., 6, 55-67.

39. Saipan, P., Tengjaroenkul, P.B. and Prahkarnkaeo, P.K. (2014) Accumulation of arsenic and cadmium in foods of animal origin collected from the local markets in northeastern region Thailand. Int. J. Anim. Vet. Adv., 6, 130-134.

40. Meepun, N., Saguansakbaramee, N. and Wongchuphan, R. (2014) Analysis of lead and cadmium contents in local vegetables in Surat Thani, Thailand. Walailak. J. Sci. Technol., 6, 455-461.

41. Kerdthep, P., Tongyonk, L., and Rojanapantip, L. (2009) Concentrations of cadmium and arsenic in seafood from Muang District, Rayong Province. J. Health Res., 23, 179-184.

42. Rangkadilok, N., Siripriwon, P., Nookabkaew, S., Suriyo T. and Satayavivad, J. (2015) Arsenic, cadmium, and manganese levels in shellfish from Map Ta Phut, an industrial area in Thailand, and the potential toxic effects on human cells. Arch. Environ. Contam. Toxicol., 68, 169-180.

43. ACFS (National Bureau of Agricultural Commodity and Food Standards). (2006) Food Consumption Data of Thailand. Available from: http://consumption.acfs.go.th/index.php.

44. Swaddiwudhipong, W., Limpatanachote, P., Mahasakpan, P., Krintratun, S. and Padungtod, C. (2007) Cadmium-exposed population in Mae Sot District, Tak Province: 1. Prevalence of high urinary cadmium levels in the adults. J. Med. Assoc. Thailand, 90, 143-148.

45. Limpatanachote, P., Swaddiwudhipong, W., Mahasakpan, P., Krintratun, S. (2009) Cadmium-exposed population in Mae Sot District, Tak Province: 2. Prevalence of Renal dysfunction in the adults. J. Med. Assoc. Thailnad, 92, 1345-1353.

46. Swaddiwudhipong, W., Limpatanachote, P., Mahasakpan, P., Krintratun, S., Punta, B., Funkhiew, T. (2012) Progress in cadmium-related health effects in persons with high environmental exposure in northwestern Thailand: A five-year follow-up. Environ. Res., 112, 194-198. 